\title{
Proteins and proteolytic activity changes during refrigerated storage in sea bass (Dicentrarchus labrax L.) muscle after high-pressure treatment
}

\author{
Romuald Chéret ${ }^{1,2}$, Aránzazu Hernández-Andrés ${ }^{3}$, Christine Delbarre-Ladrat ${ }^{2}$, \\ Marie de Lamballerie ${ }^{1}$ and Véronique Verrez-Bagnis ${ }^{2^{\star}}$
}

\author{
${ }^{1}$ UMR CNRS 6144 GEnie des Procédés Environnement et Agroalimentaire, École Nationale d'Ingénieurs des \\ Techniques des Industries Agricoles et Alimentaires, BP 82225, 44322 Nantes Cedex 3, France \\ ${ }^{2}$ IFREMER, Rue de l'lle d'Yeu, BP 21105, 44311 Nantes Cedex 3, France \\ ${ }^{3}$ Instituto del Frío (CSIC), C/José Antonio Nováis, 10, 28040 Madrid, Spain \\ *: Corresponding author : veronique.verrez@ifremer.fr
}

\begin{abstract}
Contrary to other preservation methods like thermal treatments, high pressure can destroy microorganisms without affecting the nutritional quality, color, or food texture. The firm texture of fish flesh is an important quality parameter. During the refrigerated storage, the tissue becomes softer and the muscle is deteriorated by different proteases. The aim of this study was to study the modification of the fish muscle proteins after high-pressure treatment during the refrigerated storage and to evaluate the effect of high-pressure treatment level on the post-mortem protein changes and enzyme activities. The calpain activity decreased with the high-pressure treatment and evolved differently during the refrigerated storage, depending on the level of pressurisation. Its inhibitor, the calpastatin was not affected by high pressure, but its inhibiting potential decreased during the post-mortem storage. The activities of cathepsins were modified by the high-pressure treatment and the time of storage, but depended according to their class. The electrophoresis profiles showed that sarcoplasmic proteins were modified according both the high-pressure treatment and the period of storage. For the myofibrillar proteins, the only changes were due to the high-pressure treatment.
\end{abstract}

Keywords: Fish - High pressure - Post-mortem denaturation - Myofibrillar proteins - Sarcoplasmic proteins - Calpains - Cathepsins 
Proteins and proteolytic activity changes during refrigerated storage in sea bass (Dicentrarchus labrax L.)

muscle after high-pressure treatment

\section{Introduction}

Freshness is one of the most important aspects of raw fish which contributes the best to define the quality of fish as food. The loss of freshness is often caused by a combination of physical, biochemical and microbiological reactions. Thus, the enzymatic degradations introduce the post-mortem softening of fish muscle and allow a proliferation of bacterial flora.

The contributions of proteolytic systems to the fish muscle degradation have been only little clarified. Calpains and cathepsins are the enzymes often cited as they seem to be involved in post-mortem tenderization $[1,2]$. The calpains and the cathepsins are thought to act in a synergistic way [2].

The calpains (EC 3.4.22.17) are intracellular endopeptidases requiring calcium for their enzymatic activity. Two isoforms are widely present in muscle: $\mu$-calpain $\left(5-50 \mu \mathrm{M} \mathrm{Ca}^{2+}\right.$ to be active) and m-calpain (150-1000 $\left.\mu \mathrm{M} \mathrm{Ca}^{2+}\right)$. The calpains are heterodimers composed of a large subunit and a small subunit with a molecular weight of about $80 \mathrm{kDa}$ and $28 \mathrm{kDa}$, respectively. Moreover, these enzymes are regulated by an endogenous specific inhibitor, the calpastatin. In sea bass muscle (Dicentrarchus labrax L.), three different isoforms have been identified [3]. The calpains seem to be responsible for the early beginning of the proteolytic degradation of myofibrils [4].

The cathepsins are "acid" proteases, which are embedded in organelles called lysosomes [5]; they are widely distributed in muscles and organs. After the death and during the storage of the muscle, they may be released into both the cytoplasm and the intracellular spaces as a consequence of lysosomal breakdown. These enzymes contribute to the breakdown of cells and tissues. Some cathepsins are regulated by an inhibitor, such as a cystatin for the cathepsins B and L. Among all the lysosomal proteases, cathepsins B (EC 3.4.22.1), D (EC 3.4.23.5) and L (EC 3.4.22.15) are often described to be involved in the softening of the fish muscle $[1,2]$. 
High-pressure treatment is an innovative food preservation technology. The high-pressure is an alternative to thermal treatment or chemical preservations. There are several highpressure processed products on the market: ham, sausages, bacon (Spain), fruit jams, fruit jellies and rice (Japan), fruit juices (France, Italy, UK, USA), guacamole, and oysters (USA). This technology allows inactivation of pathogenic and spoilage micro-organisms in foods [6]. But it exhibits also other numerous advantages. Foods have fresher taste, no vitamin $\mathrm{C}$ loss and better appearance, textural and nutritional qualities compared to other classical processing. On the top of that, consumers do not have a negative feeling of the process as it is the case with irradiation treatment [7]. Generally, the products are treated in the range of 100 to $1000 \mathrm{MPa}$, for 5 to 20 minutes. The high-pressure processing affects chemical bonds of molecules, and that may induce modifications of water, proteins, polysaccharides and lipids. This treatment can modify the hydrostatic and electrostatic molecular interactions with important consequences for the secondary, tertiary and quaternary structures of proteins. In the fish muscle, this processing affects enzymatic activities $[8,9]$ as well as structural proteins [10]. Therefore, high-pressure processing changes structural matrix of muscle and consequently the texture [8].

The aim of the study was to understand how the proteolytic enzymes behave during the refrigerated post-mortem storage after different high pressure treatments of fish muscle and how the sarcoplasmic and myofibrillar proteins were modified

\section{Materials and methods}

\section{1. Materials}

Unless specified, chemicals were purchased from Sigma-Aldrich (Saint-Quentin Fallavier, France). The chromatographic gels were from Amersham Biosciences (Uppsala, Sweden). 
94

\subsection{Preparation of the fish samples}

Twelve farmed fresh sea bass (Dicentrarchus labrax L.), 4 years old, with an average weight of $325 \mathrm{~g}$ and total length of $30 \mathrm{~cm}$ were collected from a local aquaculture farm ('Les Viviers du Gois', Beauvoir-sur-Mer, France) and brought back alive to the laboratory. Fish were killed by decapitation, dorsal white muscle was excised and skinned in pre-rigor conditions. To reduce the effect of fish variation, both dorsal fillets of each fish were divided into portions and mixed to finally obtain out twelve homogeneous samples each of about 100 g.

\subsection{High-Pressure Processing}

High-pressure processing was carried out in a $3.5 \mathrm{~L}$ vessel (ACB Pressure Systems, Nantes, France) equipped with temperature and pressure regulator device. Prior to pressure processing, sea bass muscle samples at the day of death prepared as described above were individually packed under vacuum in polyethylene bags (La Bovida, France). The samples were subsequently subjected to high-pressure treatment: 4 samples at $100 \mathrm{MPa}$ and 4 samples at $300 \mathrm{MPa}( \pm 7 \mathrm{MPa})$ for 5 minutes. The remaining four samples were studied without pressurization as control. The expected high-pressure was reached at $3 \mathrm{MPa} / \mathrm{s}$, and after 5 minutes was then quickly released $(250 \mathrm{MPa} / \mathrm{s})$. Temperature of transmitting medium in the vessel was settled at $10^{\circ} \mathrm{C}\left( \pm 5^{\circ} \mathrm{C}\right)$. Temperature of the cooling jacket which surrounded the pressure vessel was also controlled at $10{ }^{\circ} \mathrm{C}$ during pressure treatment. One thermocouple Ktype (0.3 mm diameter, Omega, Stamford, Connecticut, USA) positioned close to sample allowed to follow temperature variation during treatment.

\subsection{Storage of fillet}


The figure 1 summarizes the planning of the experimentation. After each pressurization, the different portions of muscles were stored at $4{ }^{\circ} \mathrm{C}$ from 0 to 7 days. At the end of the appropriate storage period, three portions of $30 \mathrm{~g}$ in triplicates were minced and vacuum packed (triplicate samples). And finally, the minced muscle samples were frozen at $-80^{\circ} \mathrm{C}$ until use.

\subsection{Preparation of sarcoplasmic proteins from sea bass muscle}

$25 \mathrm{~g}$ of frozen minced muscle was homogenized twice for $30 \mathrm{~s}$ with Ultra Turrax (T25, in $75 \mathrm{ml}$ of buffer A containing $50 \mathrm{mM}$ Tris- $\mathrm{HCl}(\mathrm{pH} 7.5), 10 \mathrm{mM} \beta$-mercaptoethanol and 1 $\mathrm{mM}$ ethylenediaminetetraacetic acid (EDTA). After centrifugation at $10000 \times \mathrm{g}$ (GR 20.22,

130 Jouan, France) for $40 \mathrm{~min}$ at $10^{\circ} \mathrm{C}$, the supernatant was filtered through a $0.45 \mu \mathrm{m}$ filter

131 (Sartorius AG, Goettingen, Germany). Three sarcoplasmic extracts were realized for each pressure treatment and for different post-mortem storage days.

\subsection{Preparation of myofibrillar proteins}

$5 \mathrm{~g}$ of dorsal frozen fish muscle was homogenized with 4 volumes of buffer A with Ultra Turrax (T25, IKA, Labortechnik, Staufen, Germany) (22000 rpm) during 1 min. After centrifugation at $10000 \mathrm{xg}$ (GR 20.22, Jouan, France) for $40 \mathrm{~min}$ at $10^{\circ} \mathrm{C}$, the pellet was

138 again homogenized with 4 volumes of buffer A with Ultra Turrax (T25, IKA, Labortechnik,

139 Staufen, Germany) (22000 rpm) during $1 \mathrm{~min}$. This homogenate was centrifuged at $10000 \mathrm{x}$

$140 \mathrm{~g}$ (GR 20.22, Jouan, France) for $40 \mathrm{~min}$ at $10^{\circ} \mathrm{C}$. The pellet was collected and resuspended in

141 buffer containing $0.04 \mathrm{M}$ potassium di-hydrogen phosphate, $0.04 \mathrm{M}$ di-potassium hydrogen

142 phosphate and $0.6 \mathrm{M}$ potassium chloride at $\mathrm{pH}$ 6. The protein concentration of the different

143 samples was adjusted to $4 \mathrm{mg} / \mathrm{ml}$. 


\subsection{Purification of calpains from muscle}

The whole procedure was carried out at $4^{\circ} \mathrm{C}$. The chromatographic column (Phenyl

147 Sepharose, $\phi 26 \mathrm{~mm}$, L $10.5 \mathrm{~cm}$ ) was balanced with equilibration buffer composed of 50\%

148 buffer $\mathrm{A}$ and $50 \%$ buffer $\mathrm{B}$ (buffer $\mathrm{A}$ with $1 \mathrm{M} \mathrm{NaCl}$ ).

149 Fifty milliliters of sarcoplasmic extract with $0.5 \mathrm{M} \mathrm{NaCl}$ (final concentration) were directly

150 run onto the chromatographic column. The non-absorbed proteins, including calpastatin, the

151 endogenous inhibitor of calpains, were washed with the equilibration buffer. The calpain

152 active fractions were then eluted in batch with buffer A. These different protein peaks were

153 collected in ice.

\subsection{Determination of proteins}

The amount of proteins was evaluated by Biuret method according to Gornall et al. [11] with bovine serum albumin solution as the standard. The values were the means of three measurements for each sample.

\subsection{Calpain activity measurement}

161 Calpain activity was determined in triplicate at $30^{\circ} \mathrm{C}$ in a $303 \mu 1$ reaction mixture

162 containing $3 \mu \mathrm{l}$ of $0.5 \mathrm{M} \mathrm{CaCl}_{2}, 6 \mu \mathrm{l}$ of $5 \%$ CHAPS \{3-[3-(cholamidopropyl)-dimethyl-

163 ammonio]-1-propanesulfonate $\}$ and $5 \mu 1$ of $20 \mathrm{mM}$ synthetic fluorogenic substrate SucLT (N-

164 Succinyl-Leu-Tyr-7-amido-4-methylcoumarin) prepared in methanol. The reaction was

165 initiated by adding $255 \mu 1$ of enzymatic sample. During a fourty minutes reaction,

166 fluorescence was monitored in microplate wells using the spectro-photo-fluorometer

167 FLUOstar OPTIMA POLARstar OPTIMA reader (BMG LABTECH, Champigny sur Marne,

168 France) with an excitation wavelength set at $355 \mathrm{~nm}$ and emission wavelength set at $460 \mathrm{~nm}$. 
169 A control in which $3 \mu 1$ of $0.5 \mathrm{M} \mathrm{CaCl}_{2}$ was replaced by $3 \mu 1$ of $0.5 \mathrm{M}$ EDTA was also

170 performed. Activity was expressed in FU (fluorescence units) per minute per g of muscle. The

171 values were expressed as mean \pm Standard Deviation.

172

\subsection{Quantification of calpastatin inhibitory activity}

Calpastatin inhibitory activity was measured with a calpain-active sample produced separately from a whole fish white muscle (the non-absorbed proteins, including calpastatin), as described above. $55 \mu 1$ of calpastatin sample (or buffer for the control) was mixed with $200 \mu 1$ of calpain sample and the resulting calpain activity was measured on SucLT fluorogenic substrate as previously described. One unit of calpastatin activity was defined as the amount which inhibits one unit of calpain activity. Calpastatin activity was expressed in FU (fluorescence units) per minute per $g$ of muscle. The values were the means of three measurements for each sample.

\subsection{Activity measurement of lysosomal enzymes}

\subsubsection{Cathepsin D}

Cathepsin D activity was determined with hemoglobin as the substrate according to Anson's method [12]. Activity was determined at $37^{\circ} \mathrm{C}$ on a $8 \mathrm{ml}$ reaction mixture containing $2 \mathrm{ml}$ of $0.2 \mathrm{M}$ acetate/ acetic acid ( $\mathrm{pH} 4$ ) buffer, $10 \mathrm{mM} \beta$-mercaptoethanol, $1 \mathrm{mM}$ EDTA and $2 \mathrm{ml}$ of $2 \%(\mathrm{w} / \mathrm{v})$ denatured hemoglobin. The reaction was initiated by adding $4 \mathrm{ml}$ of sarcoplasmic protein extract and stopped by adding at different interval times $300 \mu 1$ of $10 \%$ trichloroacetic acid (TCA) to $300 \mu 1$ of mixture reaction sampled. After an overnight incubation at $4^{\circ} \mathrm{C}$, the sample was centrifuged at $18000 \times \mathrm{g}$ for $15 \mathrm{~min}$ at $10^{\circ} \mathrm{C} .150 \mu \mathrm{l}$ of supernatant reacted with $150 \mu \mathrm{l}$ of Bio-Rad Protein assay (BIO-RAD Laboratories GmbH, München, Germany) for the quantification of TCA-soluble peptides released by digestion. Absorbance was measured 
194 spectrophotometrically at $595 \mathrm{~nm}$. For each samples, blanks containing $40 \mu \mathrm{l}$ of $0.01 \mathrm{M}$

195 isovalerypepstatin, an effective inhibitor of cathepsin D were prepared. Cathepsin D activity 196 was obtained by the difference with and without isovalerylpepstatin. The activity was

197 expressed in $\mu \mathrm{g} / \mathrm{ml}$ of peptides liberated per minute per $\mathrm{g}$ of muscle. The values were the 198 means of three measurements for each sample.

\subsubsection{Cathepsins $B$ and $L$}

$\mathrm{B}$ and $\mathrm{L}$ cathepsin activities were determined at $30^{\circ} \mathrm{C}$ in a $298 \mu \mathrm{l}$ reaction mixture containing $70 \mu \mathrm{l}$ of $0.2 \mathrm{mM}$ acetate/ acetic acid ( $\mathrm{pH}$ 4) buffer, $10 \mathrm{mM} \beta$-mercaptoethanol, 1 mM EDTA, $6 \mu \mathrm{l}$ of $5 \%$ CHAPS, $1 \mu 1$ of $1.40 \mathrm{M}$ 2-mercaptoethanol, $16 \mu 1$ of $5 \%(\mathrm{w} / \mathrm{v})$ hydrochloride are used as the substrates for cathepsin B and cathepsins $(B+L)$ respectively. The reaction was initiated by adding $200 \mu \mathrm{l}$ of protein extract. A control with buffer A instead of enzymes was run in parallel. The activity was expressed in FU (fluorescence units) per minute per $g$ of muscle. The values were expressed as mean \pm S.D. of three measurements for each sample.

\subsection{SDS polyacrylamide gel electrophoresis}

SDS polyacrylamide gel electrophoresis (SDS-PAGE) was carried out on myofibrillar 214 and sarcoplasmic protein extracts according to the method of Laemmli [13]. Protein 215 concentrations were adjusted in denaturing buffer $(10 \mathrm{mM}$ Tris-HCl $\mathrm{pH} 8,2 \% \mathrm{SDS}, 0.1 \mathrm{M}$ DTT, $0.01 \%$ bromophenol blue and $1 \mathrm{mM}$ EDTA).

Electrophoresis for the sarcoplasmic proteins were carried out using a Phast System 
polyacrylamide gels (SDS-PAGE, Phast gel, Amersham Biosciences, Uppsala, Sweden). Electrophoresis conditions were $10 \mathrm{~mA}, 50 \mathrm{~V}$ and $3.0 \mathrm{~W}$, at $15^{\circ} \mathrm{C}$ for 45 minutes. $5 \mu \mathrm{g}$ of proteins were loaded into a well. Protein bands were stained with Coomassie blue.

Electrophoresis of the myofibrillar proteins were carried out in a Mini-protean dual slab cell (Bio-Rad, Richmond, CA, USA) with $10 \%$ (w/v) polacrylamide as the separating gel and $5 \%(\mathrm{w} / \mathrm{v})$ as the stacking gel. $24.5 \mu \mathrm{g}$ of proteins were loaded into a well. Gel was stained with Coomassie blue.

Two molecular weight marker sets were used: high molecular weight range markers SDS-6H (205 kDa, 116 kDa, 97.4 kDa, 66 kDa, 45 kDa, 29 kDa) (Sigma markers, Saint Louis, USA) and low molecular weight range markers SDS-7 (66 kDa, 45 kDa, 36 kDa, 29 kDa, 24 kDa, 20 kDa, 14.2 kDa) (Sigma markers, Saint Louis, USA).

\section{Results and discussion}

\subsection{Effect of high pressure and storage on the calpain and calpastatin activities}

The figure 2 illustrates the evolution of the activity of the calpains after the high-pressure treatment through the time of post-mortem storage. When the muscle has not been previously submitted to high-pressure, global calpain activity was stable during seven days post-mortem. Conversely, Delbarre-Ladrat et al. [4] have showed a significant decline in post-slaughter sea bass m-calpain activity. This difference might be explained by an important inter-individual variability which is erased in our experiment. Initial calpain activity is not affected by pressurization at $100 \mathrm{MPa}$; but it increased during the first two days of storage after treatment

240 before decreasing on the following days. The initial increase of activity could be due to a structural modification which allows a better affinity between enzyme and substrates. In the 
modifications and a dissociation of the two calpain subunits $[14,15]$, which can in certain cases induce a loss of activity related to a further autolysis of dissociated calpain [16]. In our experiments, we observe this calpain inhibition only after a $300 \mathrm{MPa}$ treatment.

Furthermore, as seen in figure 3, the inhibiting potential of calpastatin is slightly reduced during post-mortem storage. Delbarre-Ladrat et al. [4] have shown that the calpastatin activity remained rather constant during post-mortem storage. The calpains may be responsible for the proteolytic degradation of the calpastatin and also this inhibitor loosed this activity [17]. This phenomenon may explain this result. Figure 3 shows that application of pressure on white fish muscle does not affect the calpastatin activity. Moreover, Goll at al. [18] studies established that this inhibitor was a heat-stable protein which is resistant to denaturing agents such as urea, SDS and trichloroacetic acid [18]. All these data show that calpastatin is a remarkably stable protein including under high pressure treatment.

\subsection{Effect of high pressure and storage on the cathepsins activities}

The figures 4, 5 and 6 show the evolution, respectively, of cathepsins $\mathrm{D}, \mathrm{B}$ and $(\mathrm{B}+\mathrm{L})$ activities upon the refrigerated storage following high-pressure treatment. As for the calpains, significant modifications were observed according to the high-pressure treatment and the period of storage at $4^{\circ} \mathrm{C}$. First of all the activity of day 0 increased with the pressure level. For the three cathepsins, this increase is probably linked to the damaging of the lysosomal membrane: the physical constraints generated by the high-pressure treatment lead to the rupture of membrane and consequently to a release of these enzymes $[19,20]$.

During the refrigerated storage, the activity of the cathepsin D increased for the control samples: the cathepsins are released during the storage because the lysosomal membrane damaged naturally. The liberation of the proteases was often explained by a fall of the $\mathrm{pH}$ [21], but in our study, the $\mathrm{pH}$ did not evolve significantly (data not shown). During the rigor 
development, the ATP stores drop. This loss of ATP provokes a failure of ionic membranous pumps and finally leads to a damaging of lysosomal membrane, as described by Hopkins (2000) relayed by Sentandreu et al. [22].

For the pressurized samples, the activity of cathepsin $D$ increased at the $2^{\text {nd }}$ day of storage, then diminished at the $7^{\text {th }}$ day. At the $7^{\text {th }}$ day, at the loss final cathepsin $\mathrm{D}$ activity increased with the level of pressure. High-pressure treatment induces an important release of the proteases from lysosomes, but probably provokes a partial denaturation of the cathepsin D structure.

During the storage, the activity of cathepsin B decreased at the $2^{\text {nd }}$ day of storage and then, the activity remained constant for the five remaining days of storage. For the cathepsins $(B+L)$, the activity decreased lightly after two days of storage and then remained also stable.

280 For both enzymes, the initial activity increases with the high pressure treatment; this shows the destruction of lysosomes.

\subsection{Effect of high-pressure and storage on the sarcoplasmic and myofibrillar}

\section{proteins.}

The figure $7 \mathrm{~A}$ and $\mathrm{B}$ present whole sarcoplasmic and myofibrillar proteins in the dorsal white fish muscle. The sarcoplasmic proteins are mainly composed of enzymes which play a role in the energy-producing metabolism [23]. 12 major bands are present in the electrophoretic profiles and are also described by Nakagawa et al. [24]. The different proteins bands can be listed: $97 \mathrm{kDa}$, a doublet at $60 \mathrm{kDa}, 51 \mathrm{kDa}$, a 41-39 kDa huge bands. These last were probably, respectively, creatine kinase and aldolase [24]. The $36 \mathrm{kDa}$ components assumed to be glyceraldehydes-3-phosphate dehydrogenase. The supplementary bands were 
On the electrophoresis of myofibrillar proteins, 8 bands were mainly observed: myosin (at about $200 \mathrm{kDa}$ ), $\alpha$-actinin, desmin, actin, tropomyosin, $32 \mathrm{kDa}$ band (this band may result from the degradation of tropomyosin by cathepsin B and L [25]), 22 and $16 \mathrm{kDa}$ bands. intensities. The proteins of 21.5, 51 and $97 \mathrm{kDa}$ molecular weight are more intense with the high-pressure treatment. Therefore the sarcoplasmic proteins are more efficiently extracted with the increased pressure of the treatment. At the death time, for the control, the bands (doublet at $20.5 \mathrm{kDa}$ and $30.5 \mathrm{kDa}$ ) are not present, but they appeared after two days of post-mortem storage. Several studies showed that the major sarcoplasmic proteins are conserved during the storage $[25,26]$.

On the SDS-PAGE profiles on the figures $9 \mathrm{~A}$ and 9B, it can be observed that the heavy chain (MHC), the doublet (nearby $150 \mathrm{kDa}$ ), the troponin-T $(37 \mathrm{kDa})$, the $32 \mathrm{kDa}$

310 protein and the $20 \mathrm{kDa}$ protein are less intense and also some bands disappeared in a time 311 dependent way. These observations can be explained by a denaturation of the myofibrillar 312 proteins or a modification of their structure with the high pressure, which could modify their 313 extractability.

\section{Conclusions.}

316 Our results have shown that the activities of the calpains were diminished in contrast to 317 those of cathepsin which increased by a high-pressure treatment. But no significant changes 318 on the myofibrillar studied proteins during the storage are noticed. Electrophoresis are run 
under denaturing conditions, and may not allow detection of all the modifications. If the native structures of the proteins are changed, it is not observable in our experiments. The studies on the bigger myofibrillar proteins such as titin, nebulin or extracellular proteins such as collagen, elastin should also be considered in order to gain a further insight in pressure induced modification of muscular proteins.

\section{Literatured cited .}

1. Aoki T, Ueno R (1997) Food Res Int 30 (8): 585-591

2. Jiang ST (2000) Food Sci Agric Chem 2(2): 55-74

3. Ladrat C, Chaplet M, Verrez-Bagnis V, Noël J, Fleurence J (2000) Comp Biochem Physiol B 125 (1): 83-95

4. Delbarre-Ladrat C, Verrez-Bagnis V, Noël J, Fleurence J (2004) Food Chem 84 (3): 441446

5. Goll DE, Otsuka Y, Nagainis PA, Shannon JD, Sathe SK, Muguruma M (1983) muscle and J Food Biochem 7: 137-141

6. Yuste J, Capellas M, Pla R, Fung DYC, Mor-Mur MM (2001) J Rapid Meth Automation

335 Microbiol 9: 1-10

7. Deliza R, Rosenthal A, Abadio FBD, Silva CHO, Castillo C (2005) J Food Eng 67(1-2):

338 8. Angsupanich K, Ledward DA (1998) Food Chem 63 (11): 39-50

339 9. Ashie INA, Simpson BK (1996) Food Res Int 29 (5-6): 569-575

340 10. Ohshima T, Ushio H, Koizumi C (1993) Trends Food Sci Technol 4: 370-375

341 11. Gornall AG, Bardawill CJ, David MM (1949) The Journal of Biological Chemistry 177:

$342 \quad 751-766$

343 12. Anson ML, (1938) J Gen Physiol 22: 79-89 
Proteins and proteolytic activity changes during refrigerated storage in sea bass (Dicentrarchus labrax L.) muscle after high-pressure treatment

344 13. Laemmli UK (1970) Nature $227: 680-685$

345 14. Bessière P, Bancel F, Cottin P, Ducastaing A (1999) Biochem Mol Biophys 47(1): 25-35

346 15. Bessière P, Cottin P, Balny C, Ducastaing A, Bancel F (1999) Biochim Biophys Acta $347 \quad$ 1430: $254-261$

348 16. Saido TC, Sorimachi H, Suzuki K (1994) FASEB J 8: 814-822.

349 17. Mellgren RL, Mericle MT, and Lane RD (1986) Arch Biochem Biophys 246(1): 233-239

350 18. Goll DE, Thompson VF, Li H, Wei W, Cong J (2003) Physiol Rev 83: 731-801

351 19. Ohmori T, Shigehisa T, Taji S, Hayashi R (1992) Biosci Biotech Biochem 56 (8): 1285 3521288.

353 20. Jung S, de Lamballerie-Anton M, Taylor RG, Ghoul M (2000) J of Agric Food Chem 48 354 (6): $2467-2471$

355 21. Duston TR (1983) J Food Biochem 7: 223-245

356 22. Sentandreu MA, Coulis G, Ouali A (2002) Trends Food Sci Technol 13 (12): 400-421

357 23. Nakagawa T, Watabe S, Hashimoto K (1988) Nippon Suisan Gakkaishi 54 (6): 999-1004

358 24. Nakagawa T, Watabe S, Hashimoto K (1988) Nippon Suisan Gakkaishi 54 (6): 993-998

359 25. Ladrat C, Verrez-Bagnis V, Noel J, Fleurence J (2003) Food Chem 81: 517-525.

360 26. Verrez-Bagnis V, Ladrat C, Noelle J, Fleurence J (2002) J Sci Food Agric 82: 1256-1262 361

\section{Acknowledgement}

363 The authors thank the Comunidad de Madrid (CAM) for Ms. Hernández' predoctoral 364 fellowship. 


\section{Figure captions}

Figure.1. Simplistic representation of experiments.

Figure.2. Evolution of calpain activities after 0, 2, 4 and 7 days post-mortem for the different samples pressurized: $0.1 \mathrm{MPa}(\square), 100 \mathrm{MPa}\left({ }^{\circ}\right)$, and $300 \mathrm{MPa}(\otimes)$. Results are means ( \pm S.D.) of three measurements; the vertical bars represent the standard deviation. The activities are expressed in fluorescence units per minute per $g$ of muscle.

Figure.3. Evolution of calpastatin activities after 0,2, 4 and 7 days post-mortem for the different white fish muscle pressurized: $0.1 \mathrm{MPa}(\square), 100 \mathrm{MPa}(\mathbb{\square})$, and $300 \mathrm{MPa}(\otimes)$. Results are means ( \pm S.D.) of three measurements; the vertical bars represent the standard deviation. The activities are expressed in fluorescence units per minute per $g$ of muscle.

Figure.4. Evolution of cathepsin D activities after 0, 2, 4 and 7 days post-mortem for the different samples pressurized: $0.1 \mathrm{MPa}(\square), 100 \mathrm{MPa}(\mathbb{Q})$, and $300 \mathrm{MPa}\left(\mathbb{Q}^{\mathrm{Q}}\right)$. Results are means of three measurements; the vertical bars represent the standard deviation. The activities are expressed in $\mu \mathrm{g} / \mathrm{ml}$ of peptides liberated per minute per $\mathrm{g}$ of muscle.

Figure.5. Evolution of cathepsin B activities after 0, 2, 4 and 7 days post-mortem for the different samples pressurized: $0.1 \mathrm{MPa}(\square), 100 \mathrm{MPa}(\square)$, and $300 \mathrm{MPa}\left(\mathbb{Q}^{\mathrm{Q}}\right)$. Results are means of three measurements; the vertical bars represent the standard deviation. The activities are expressed in fluorescence units per minute per $g$ of muscle.

Figure.6. Evolution of cathepsins $\mathrm{B}+\mathrm{L}$ activities after $0,2,4$ and 7 days post-mortem for the different samples pressurized: $0.1 \mathrm{MPa}(\square), 100 \mathrm{MPa}(\mathbb{Q})$, and $300 \mathrm{MPa}(\mathrm{\otimes})$. Results are 
390 means of three measurements; the vertical bars represent the standard deviation. The activities

391 are expressed in fluorescence units per minute per $g$ of muscle.

393 Figure. 7. Annotated major sarcoplasmic (A) and myofibrillar proteins (B).

395 Figure.8. Effect of high pressure and post-mortem storage on the sarcoplasmic proteins 396 analysed by Coomassie blue SDS-PAGE: day 0 and 2: A; day 4 and 7: B.

398 Figure.9. Effect of high pressure and post-mortem storage on the myofibrillar proteins 399 analysed by Coomassie blue SDS-PAGE: day 0 and 2: A; day 4 and 7: B. 


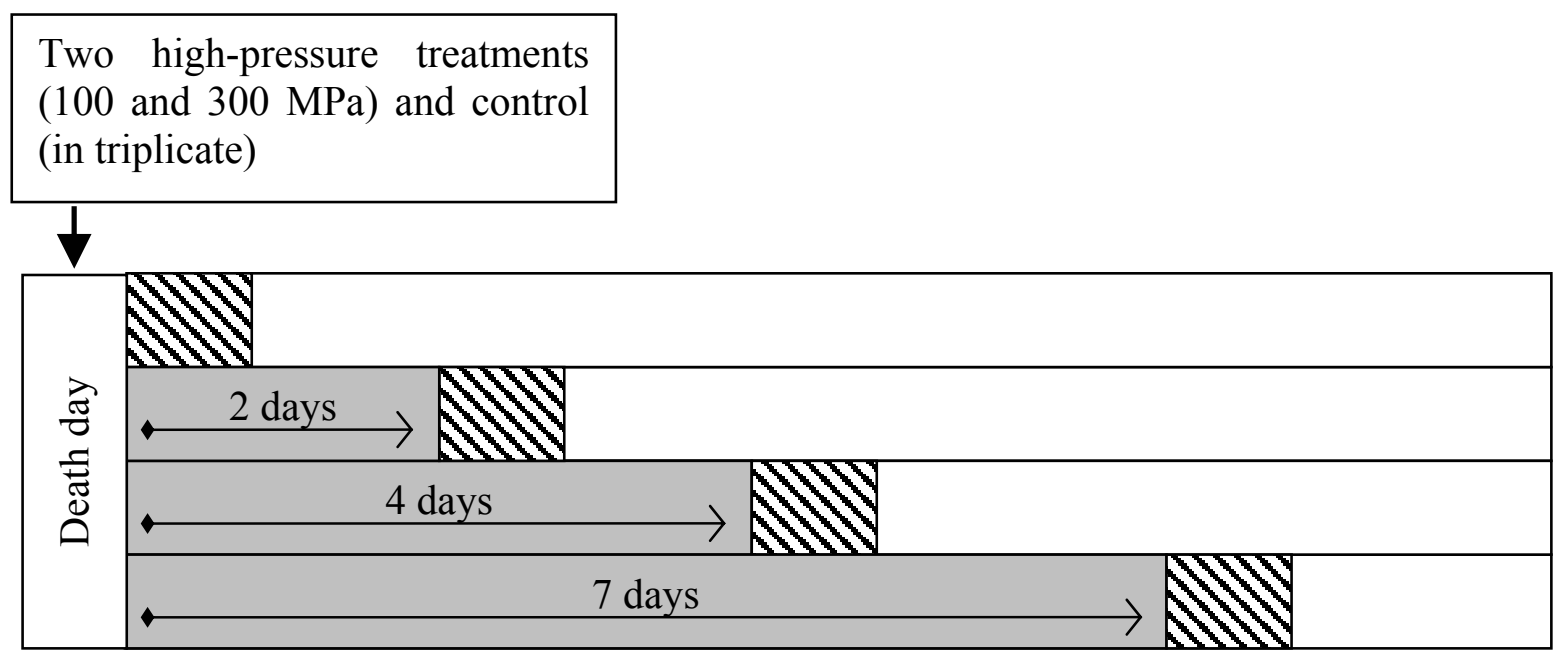

The muscles are stored at $4^{\circ} \mathrm{C}$.

The muscles are minced together and vacuum packed in $30 \mathrm{~g}$ portions ( 3 samples).

The samples are frozen at $-80^{\circ} \mathrm{C}$ until use.

Fig.1. 


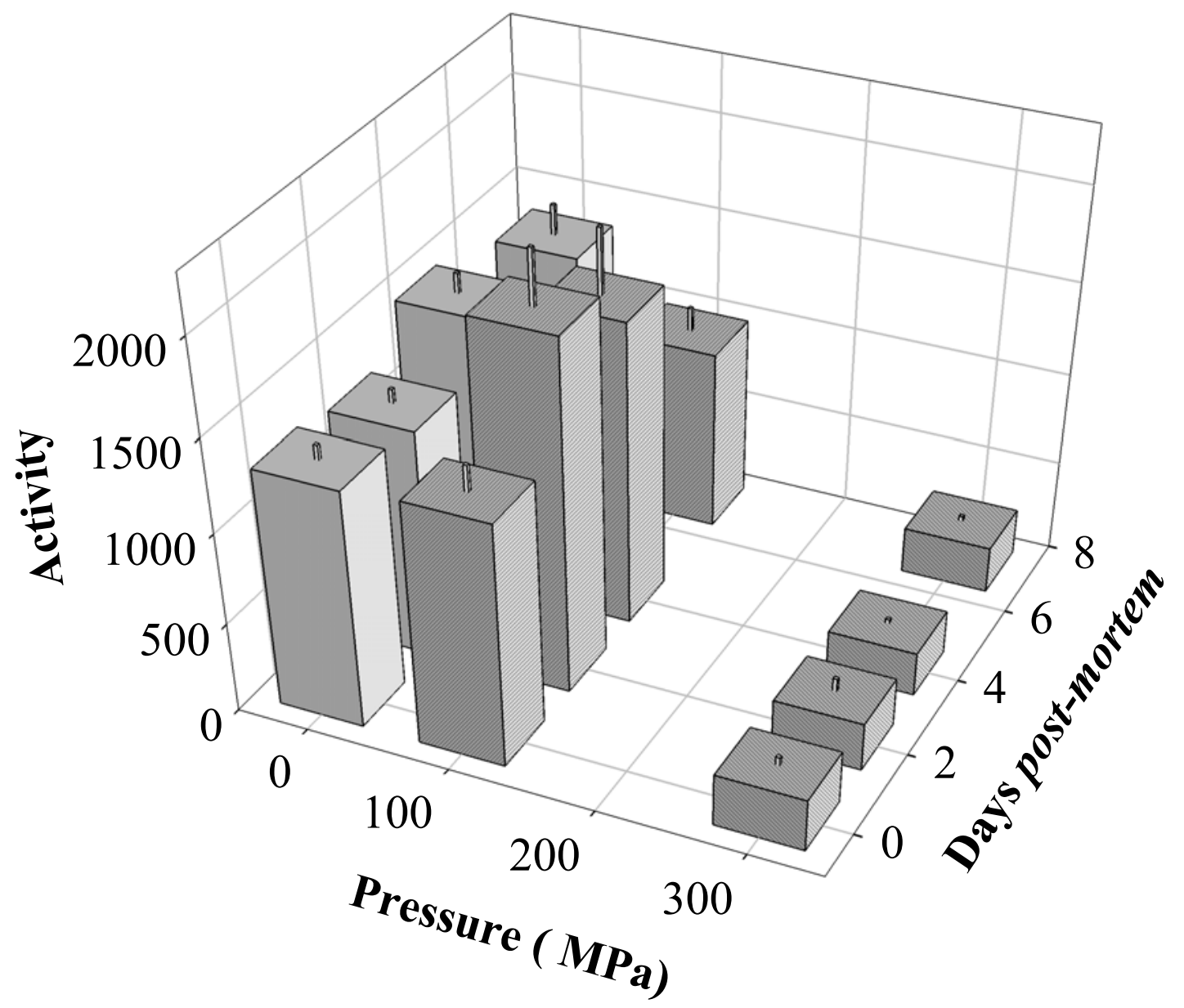

Fig.2. 


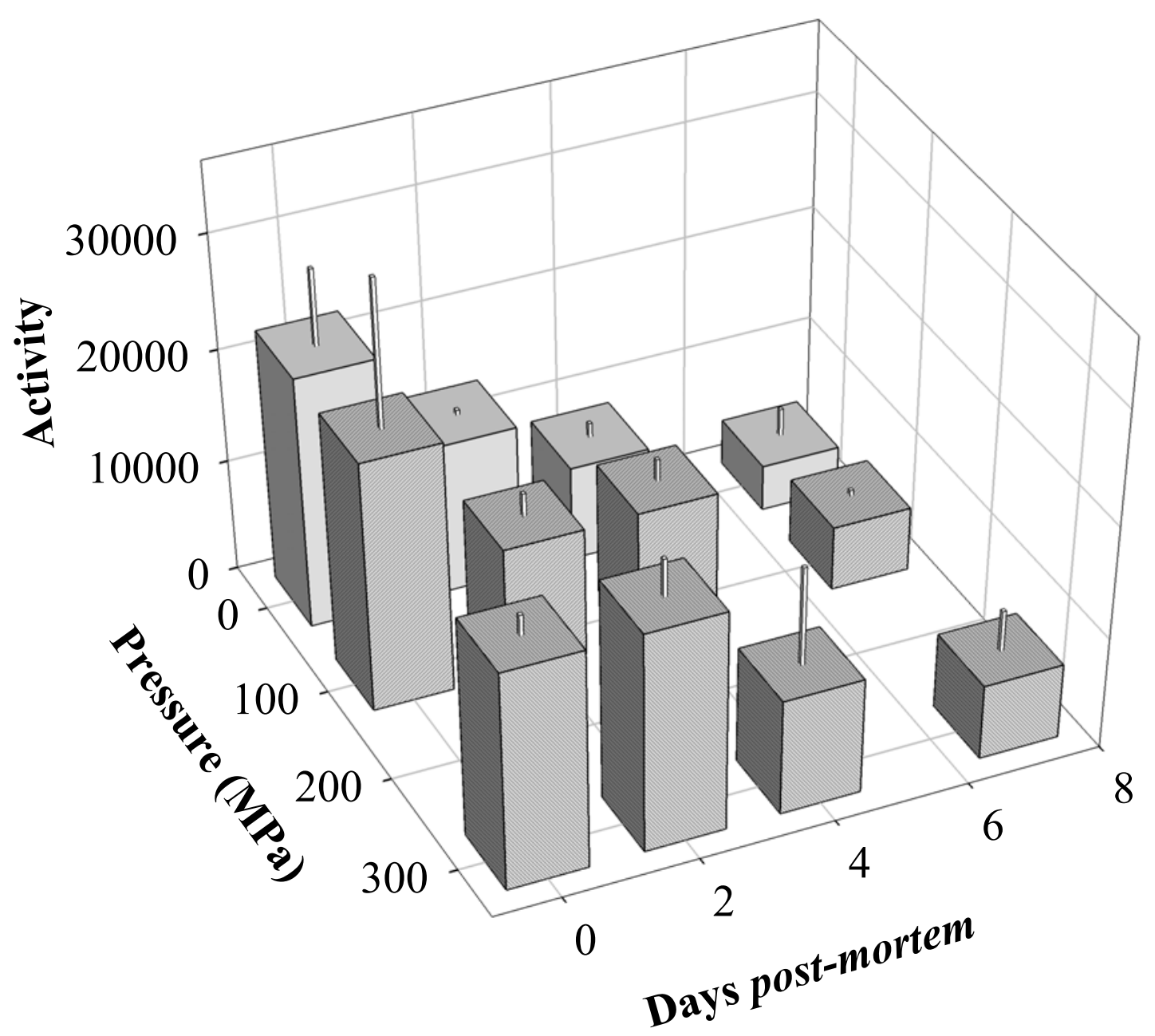

Fig 3. 


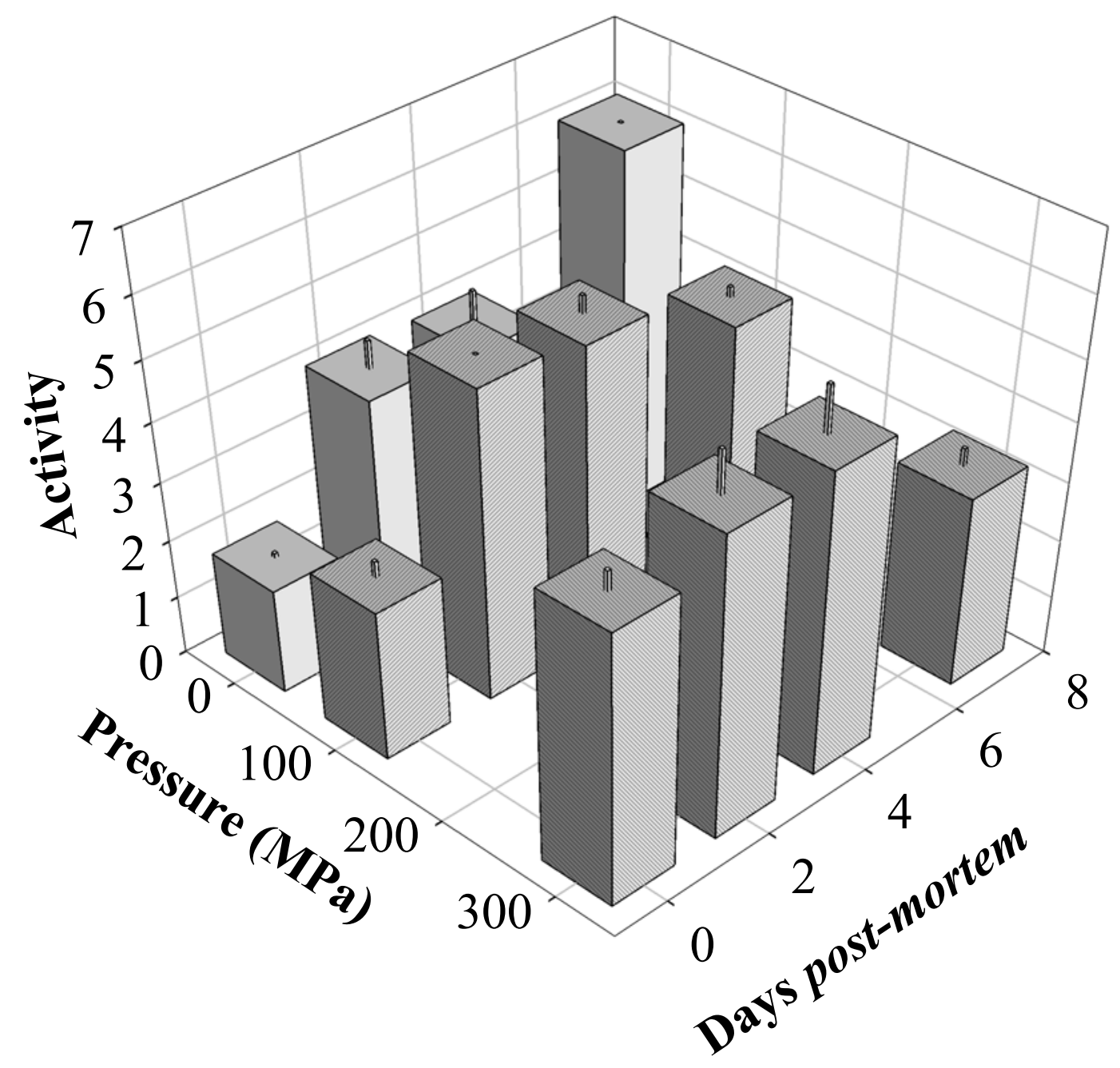

Fig.4. 


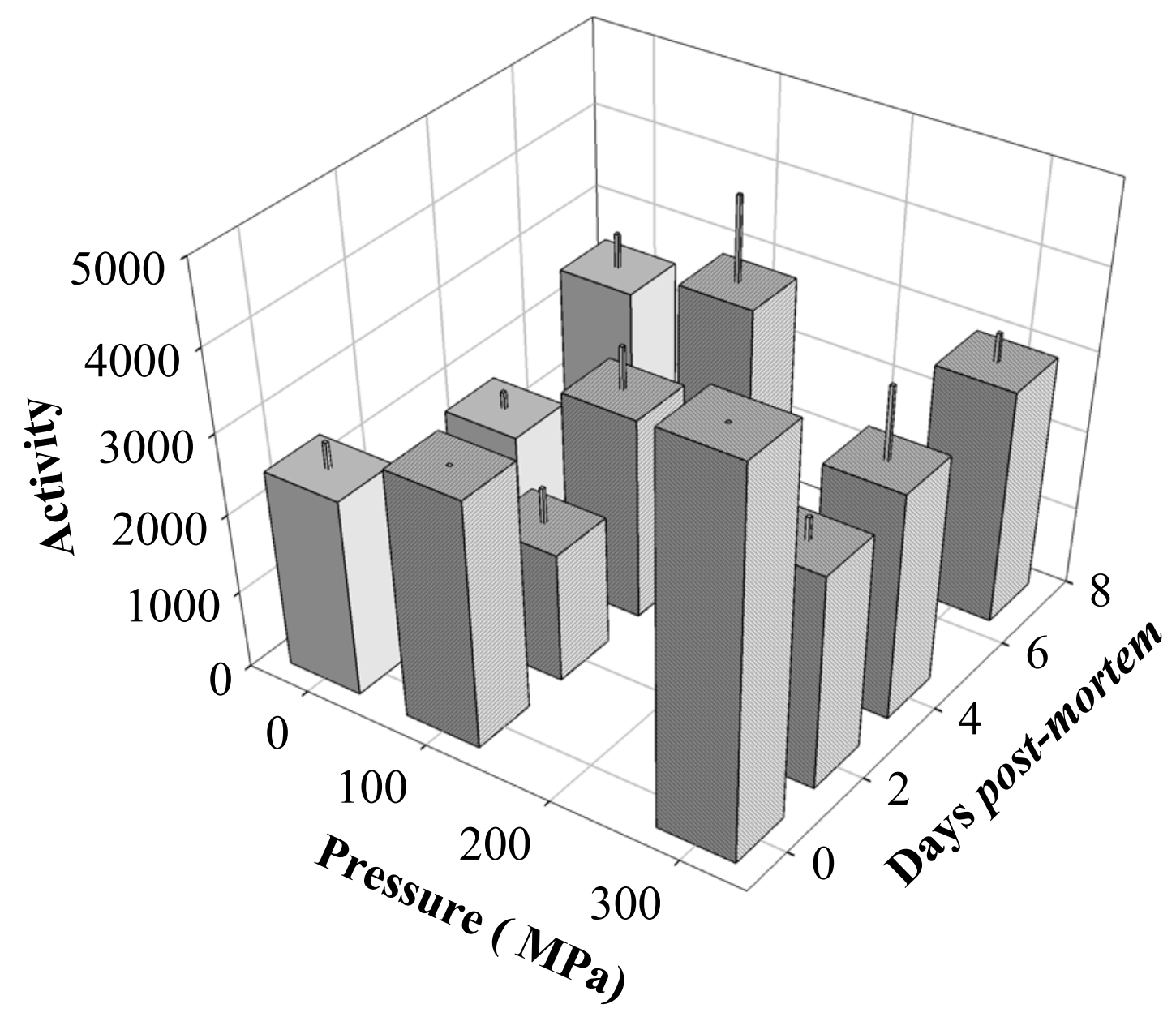

Fig.5. 


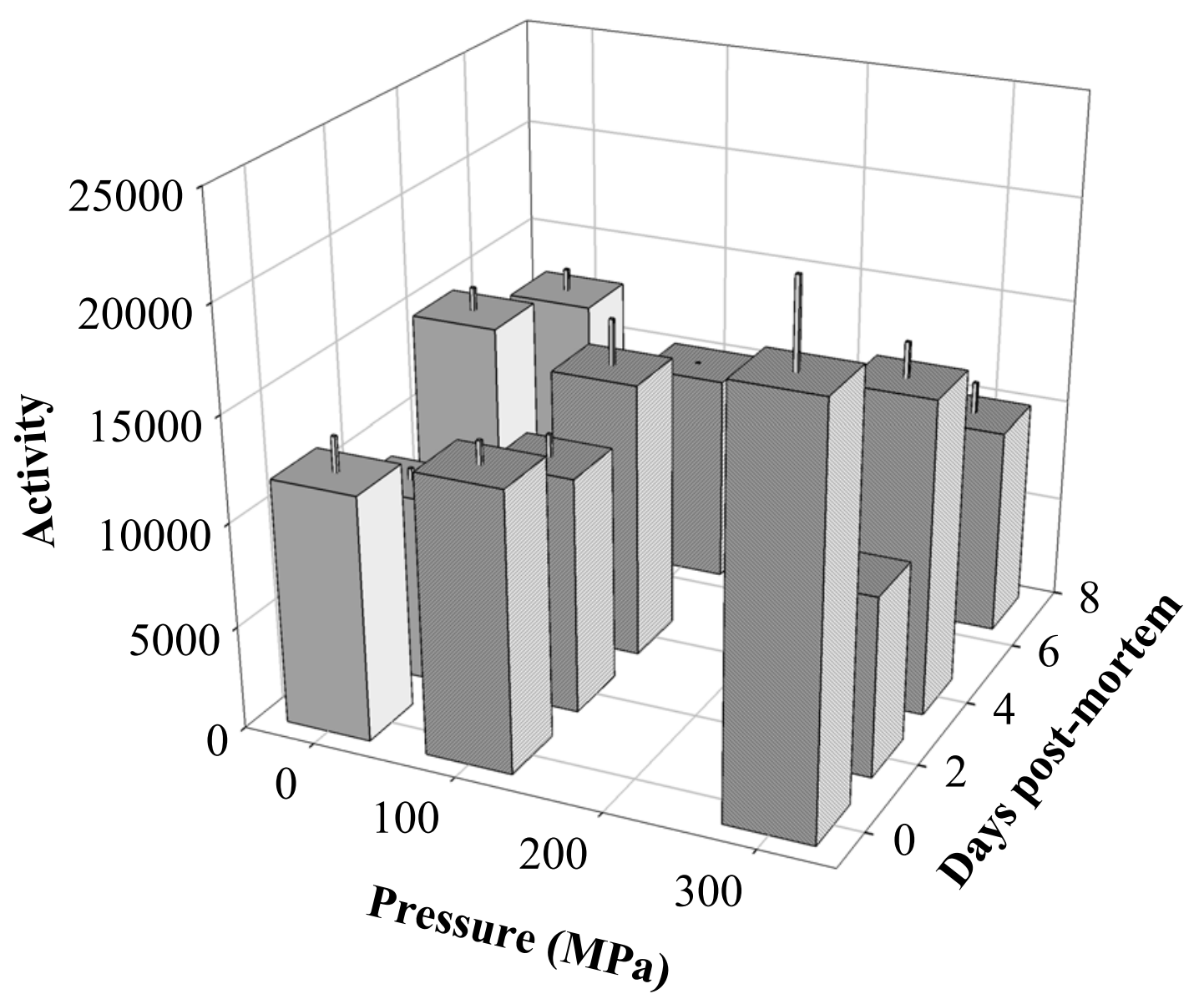

Fig.6. 
Proteins and proteolytic activity changes during refrigerated storage in sea bass (Dicentrarchus labrax L.)

muscle after high-pressure treatment

1

2

3
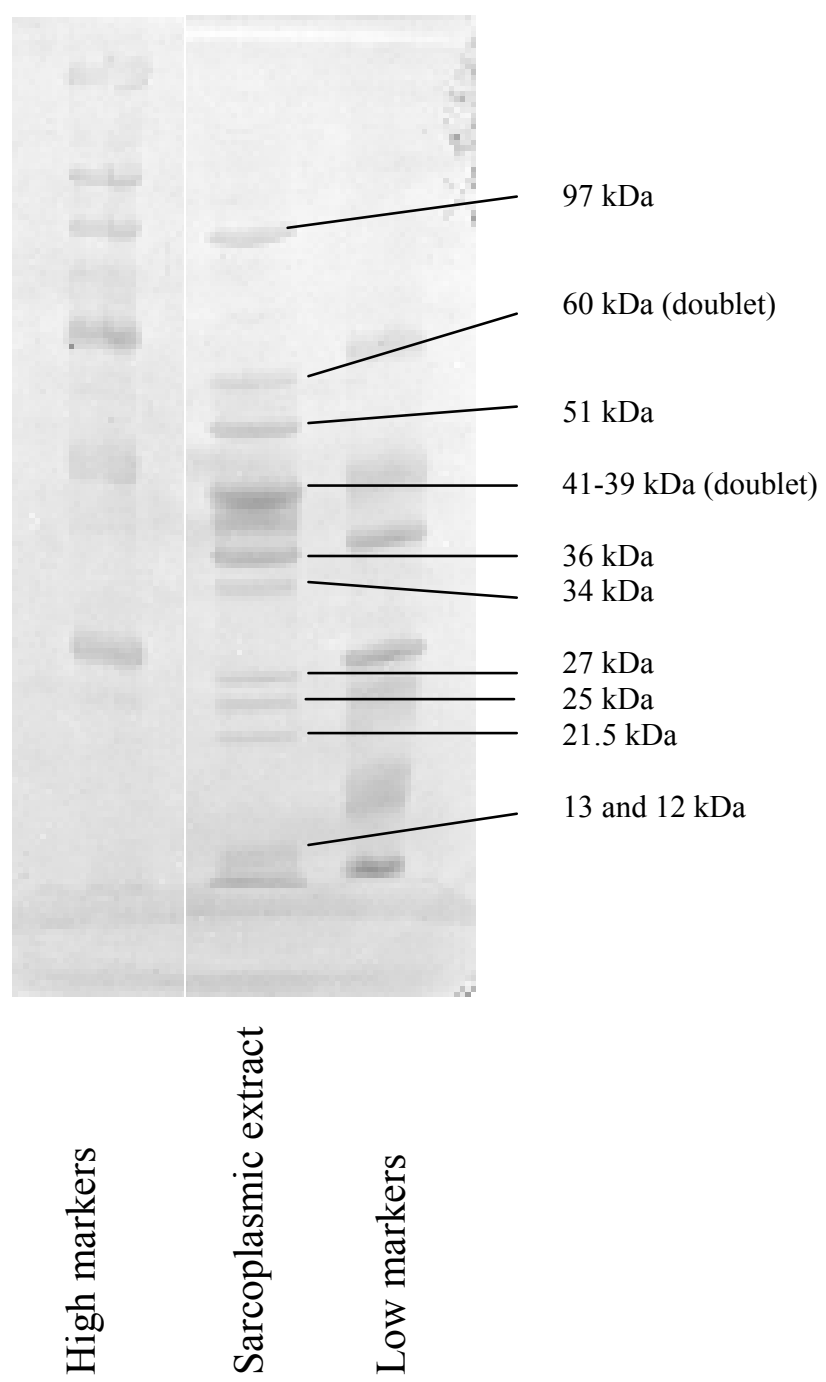

4

5

6

Fig.7A.

7

8

9

10

11

12

13 
Proteins and proteolytic activity changes during refrigerated storage in sea bass (Dicentrarchus labrax L.) muscle after high-pressure treatment

14

15

16

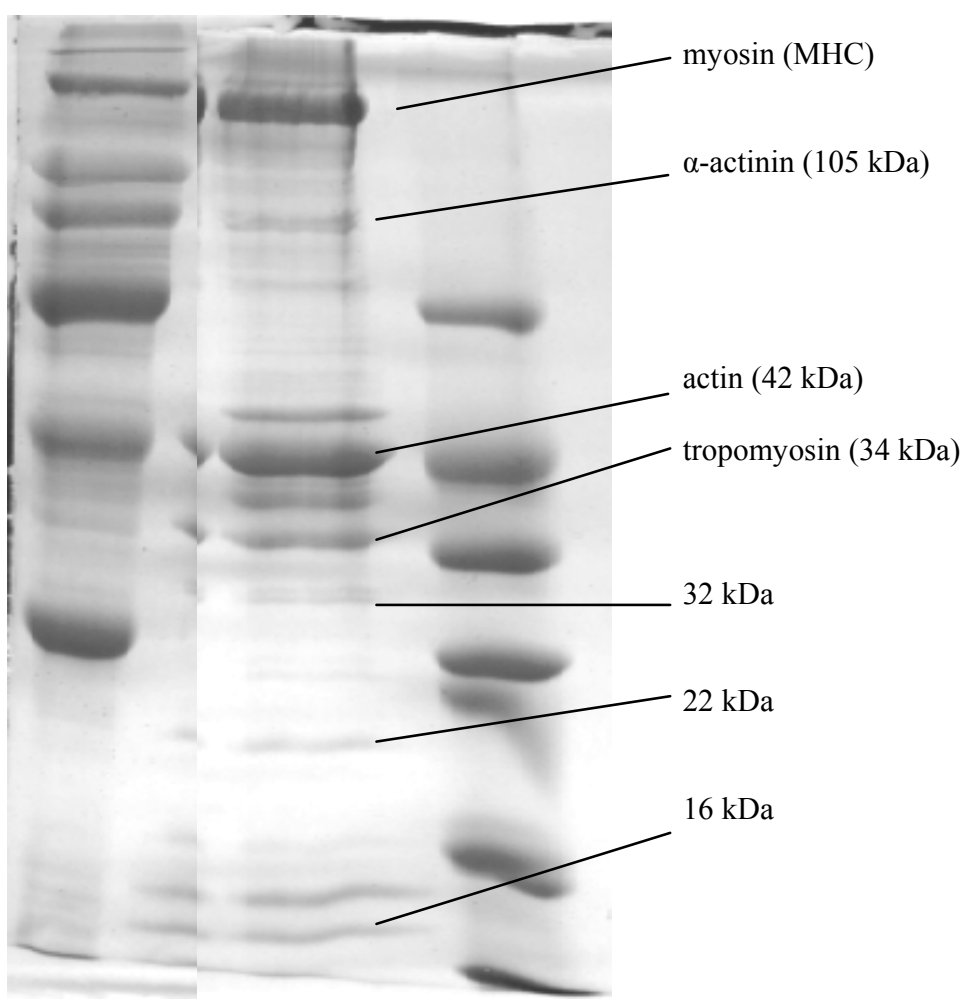

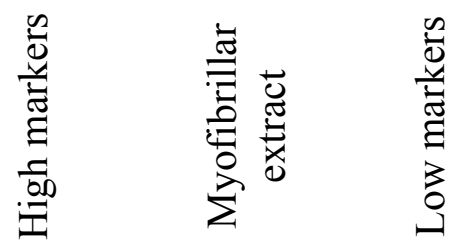

17

18

Fig. 7B.

19

20

21

22

23

24

25

26 
Proteins and proteolytic activity changes during refrigerated storage in sea bass (Dicentrarchus labrax L.)

muscle after high-pressure treatment

$205 \mathrm{kDa}$

$116 \mathrm{kDa}$

$97.4 \mathrm{kDa}$

$66 \mathrm{kDa}$
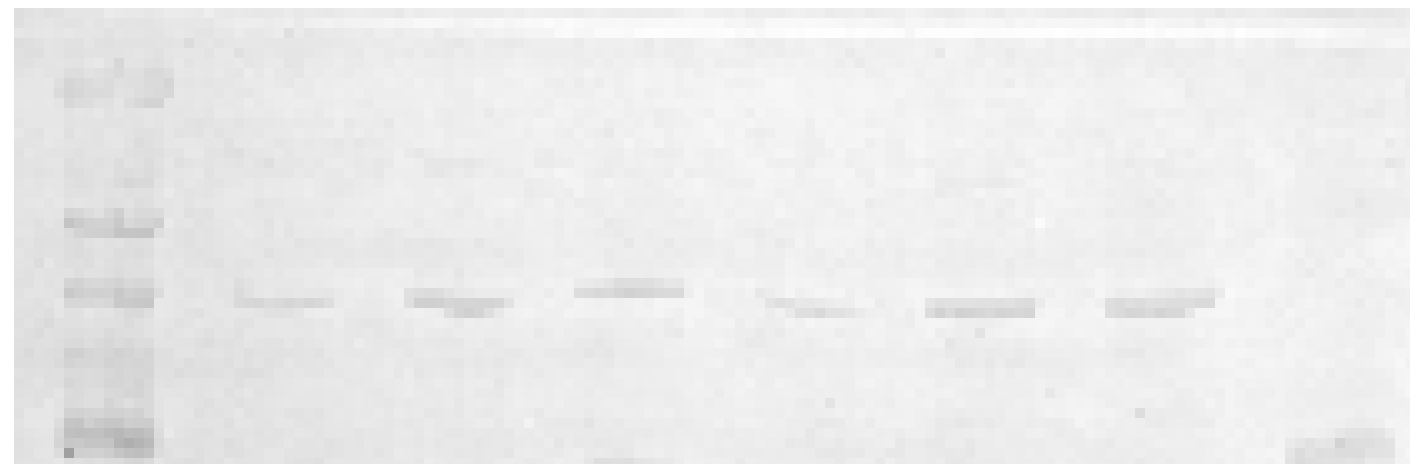

$66 \mathrm{kDa}$

$45 \mathrm{kDa}$
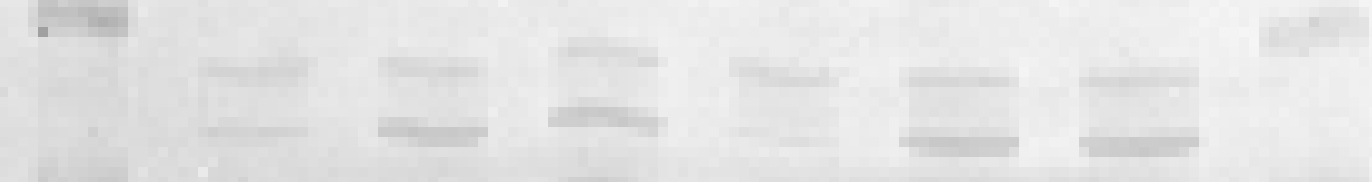

$45 \mathrm{kDa}$

$36 \mathrm{kDa}$

$29 \mathrm{kDa}$

$29 \mathrm{kDa}$

$24 \mathrm{kDa}$

$20 \mathrm{kDa}$

$14.2 \mathrm{kDa}$

2
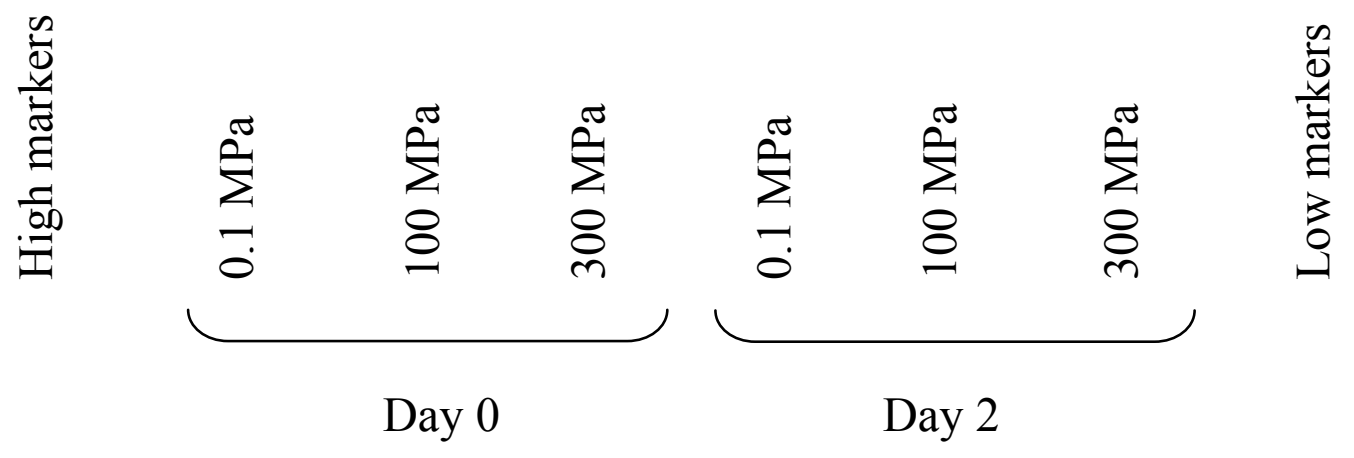

Fig. 8A.

32 
Proteins and proteolytic activity changes during refrigerated storage in sea bass (Dicentrarchus labrax L.)

muscle after high-pressure treatment

$116 \mathrm{kDa}$

$97.4 \mathrm{kDa}$

$66 \mathrm{kDa}$

$45 \mathrm{kDa}$

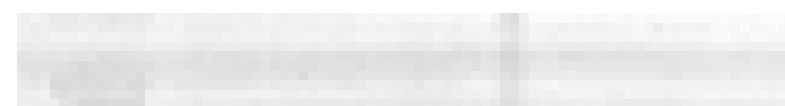

$9 \mathrm{kDa}$

3.

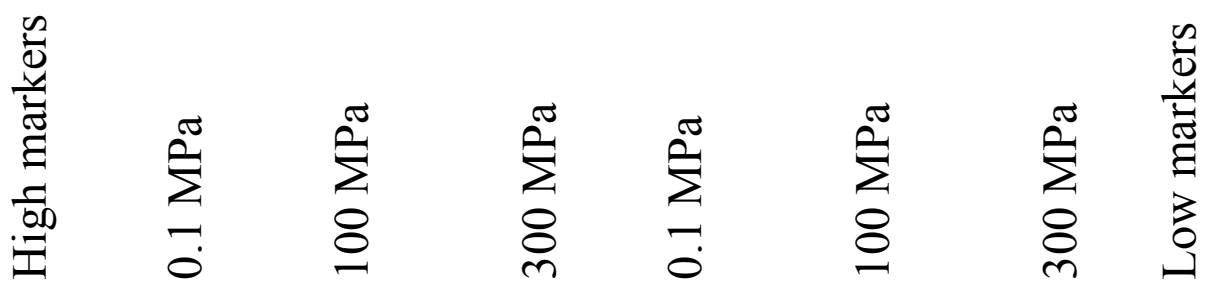

Fig. 8B. 
Proteins and proteolytic activity changes during refrigerated storage in sea bass (Dicentrarchus labrax L.)

muscle after high-pressure treatment

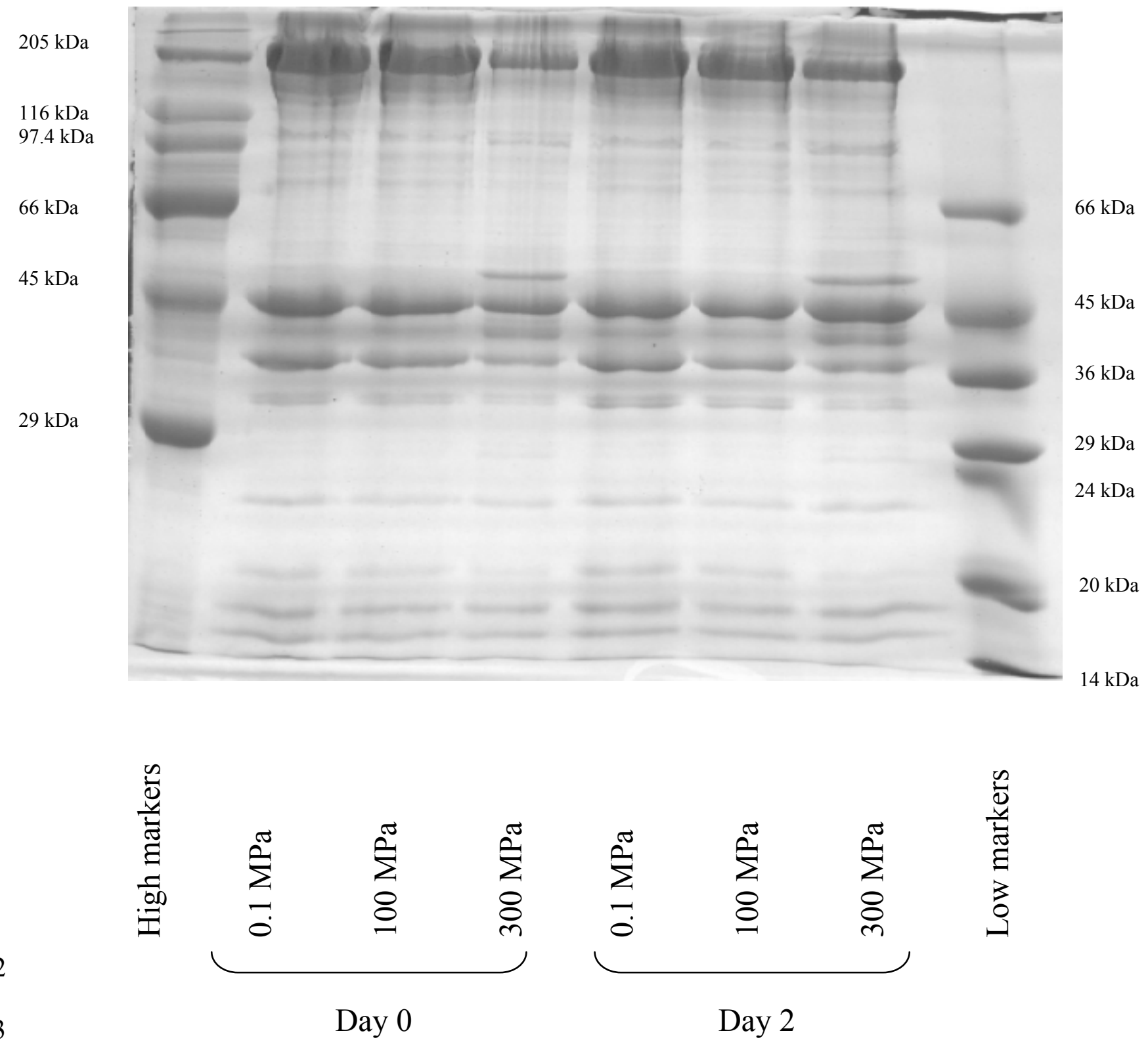


Proteins and proteolytic activity changes during refrigerated storage in sea bass (Dicentrarchus labrax L.)

muscle after high-pressure treatment

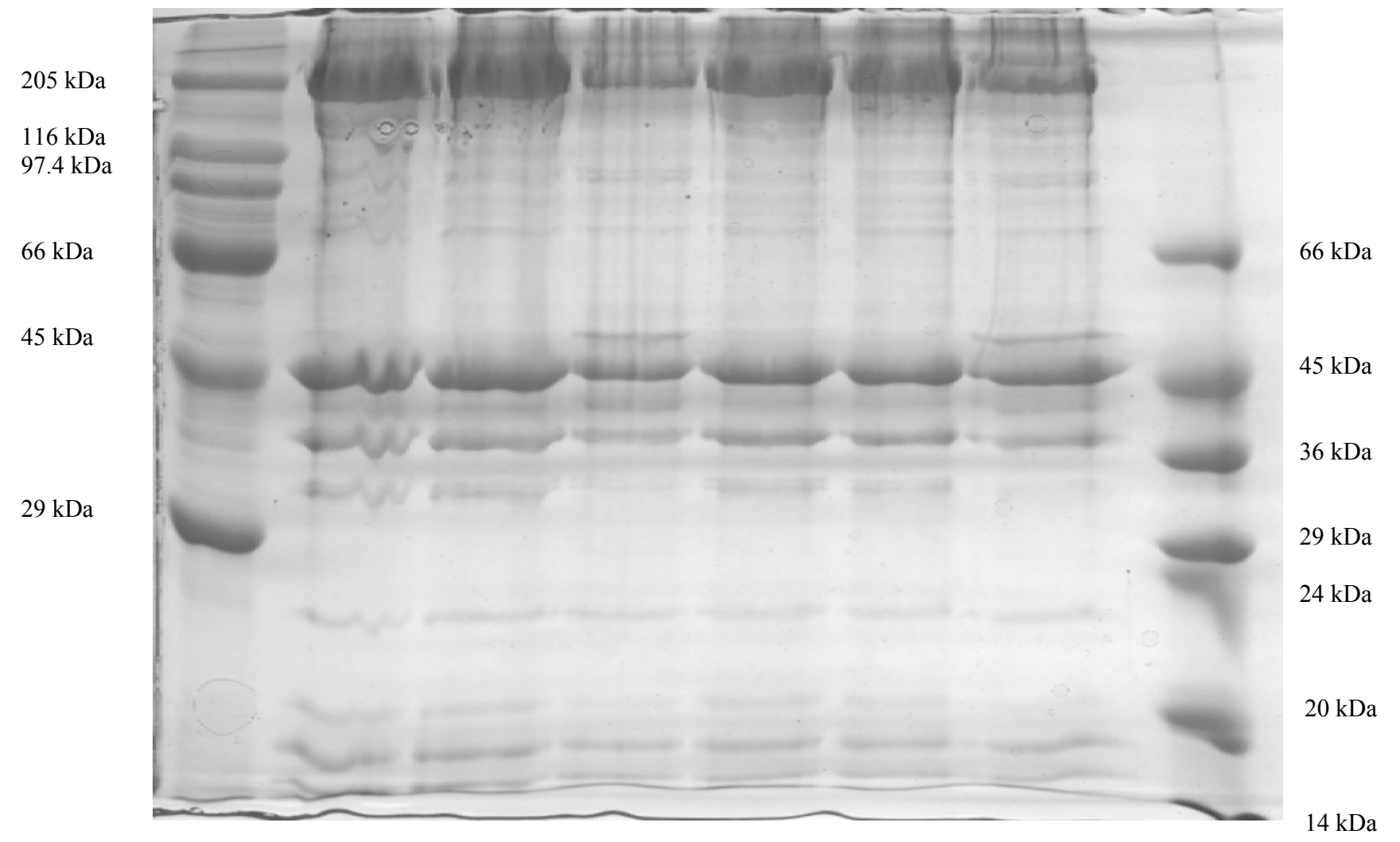

